\title{
PERFORMANCE ANALYSIS OF WATER TREATMENT PLANT USING FAILURE MODE AND EFFECT ANALYSIS METHOD AND PREVENTIVE MAINTENANCE SCHEDULING
}

\author{
IndraDwiFebryanto *) \\ ${ }^{*}$ Industrial Engineering Department, Faculty of Industrial Technology \\ University of PGRI AdiBuana Surabaya \\ email :indrafebryanto@unipasby.ac.id
}

\begin{abstract}
The availability of pure water is a basic requirement of the Company, which is one $\quad$ of the main requirements for the production process in order for the Company to produce the cream.In order to meet the production needs ,the Company must have a Water Treatment Plant with good performance. A good Water Treatment Plant can produce a lot of pure water to meet the water requirements required by the Company. This research is needed to get a good Water Treatment Plant performance to improve the pure water of Company XYZ. This research uses FMEA (Failure Mode and Effects Analysis) method to classify which components require maintenance and scheduling. Scheduling in this research using RCM (Realibility Center Maintenance) method.

In this research yield MTTRs and filter 0,48 hour, bag filter 0,68 hour, cartridge filter 1,22 hour.MTTF sanfilter 684 hours,bag filter 190.3hours, cartridge filter 236,8 hours.And MTBFs and filter with an average of 708
\end{abstract}

hours,bag filters with an average of 214.8 hours and a filter cartridge with an average of 260.8hours per year. In addition to MTTR, MTTF and MTBF other research is reliability (realibility) sand filter with value 0,178527412, bag filter with value 0,005394050 , and cartridge filter with value 0,008884653 .

KeyWord: Water Treatment Plant, FMEA, $R C M$

\section{INTRODUCTION}

In general, companies that use pure water in their products, have their own pure water-producing system so as to save expenses on the production process. Pure water producers in the company are usually referred to as WTP (Water Treatment Plant) .WTP is the basis of the optimization program that is enabled for treat water from poor quality to get a safe water quality for consumption (Pizzi, 2003). The following is a WTP process diagram:

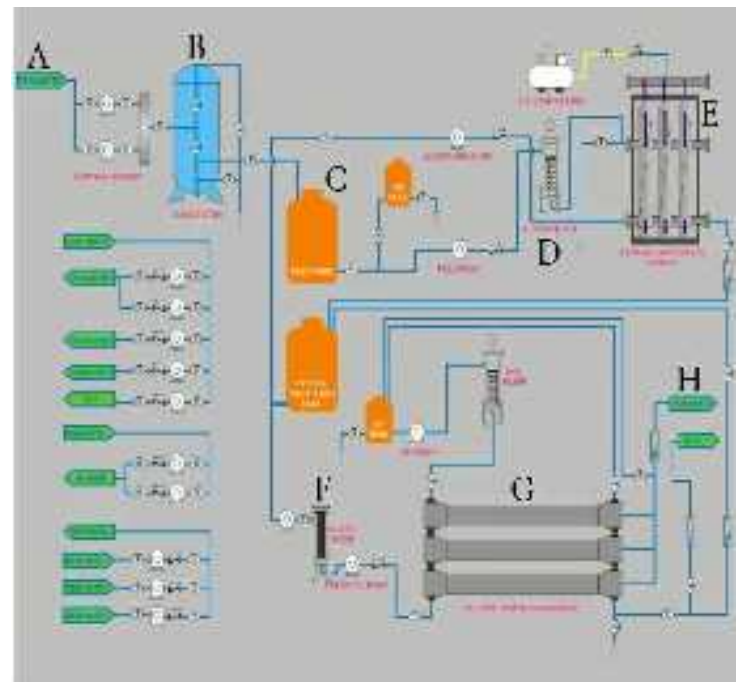

Figure 1 Water treatment process diagram on control room utility 
In the WTP system, sandfilter is the initial process of the formation of water process, so the performance of sandfilter should always be maintained so that the water produced does not inhibit the performance of UF. Backwash done in sandfilter is to clean the dirt inside the sandfilter, by way of reversing the water path through the sandfilter so that the dirt in the sandfilter can come out. With the removal of the dirt inside the sandfilter, the water produced by the sandfilter machine gets faster and more. In addition to backwash every water generated sandfilter machine less to supply UF. At the time of water supply for UF less then do backwash in sandfilter for sandfilter performance can return to normal. During this backwash process is done only based on if the water supply in UF is not normal as well as water supply on RO. The above problem is because the backwash process is not scheduled properly so it affects the need for water supply for the production process.

Several studies have been done using FMEA and RCM methods such as: Hanif, in his research on how high the level of defect in luxury palace products in a company. Hanif uses the FMEA method. The result of Hanif's research is based on RPN value of the disability analyzed that is crack disability at product surface, disability on uneven base color giving (Hanif, 2015). In addition, there is also Hakim, in his research on the effectiveness of preventative maintenance program implementation at a palm oil mill. The judge used the RCM method in his research. The results of the Judge's research are the effectiveness of preventive maintenance programs can be improved and can build regular monitoring on the machine to be well maintained (Judge, 2010). And the last one named Palit, in his research on downtime on the machine production line that often occurs in the company manifaktur aluminum, Palit using FMEA and RCM method in his research. Palit's research result is to generate RCM design proposal in the form of RCM decision from each machine component and Improvement with RCM design can decrease downtime equal to 58,07\% (Palit, 2012).

Based on the description above in this research, then will be modeled some kind of damage that happened in WTP machine by using method FMEA (Failure Mode and Effects Analysis). The FMEA method is an analytical technique that combines technology and experience in identifying production process failures and planning for damage prevention.

\section{METHODOLOGY}

The method in this research using Failure Method and Effect Analysis and Realibility Center Maintenance method. The FMEA method is a technical analysis which, if done correctly and in a timely manner, will provide great value in assisting the decision making process of the engineer during design and development. Such an analysis is usually called a "bottom up" analysis, such as an examination of the initial production process and considering system failures that are the result of a whole different form of failure (Leitch, 1995).

To determine the priority of a failure form must first identify the Severity, Occurance, Detection, and the final result of RPN.

- Severity is the first step to analyze the risk of calculating how big the impact that arises when a failure occurs. These impacts are scored from the scale of tables 1 to 10 , of which 10 are the worst.

- Occurance is a possibility of failure during the life of the product. By estimating the possibility of occurance on a scale of tables 1 to 10 .

- Detection is a measure of the ability to control or control the failure that can occur.

- Risk Priority Number (RPN) is a mathematical product of the seriousness of the effect (severity), the probability of occurrence that will cause failure associated with the effect (occurance), and the ability to detect failure before it occurs to the customer (detection).

The RCM method of reliability or reliability can be defined as the probability that a component or system will inform a function that is required within a given time period when used under operating conditions (Ebeling, 1997). Preventive maintenance can be interpreted as a maintenance action to keep the system or sub-assembly in order to keep operating in accordance with its function by preparing inspection in systematic, detection, and correction on minor damage to prevent.

- Preventive maintenance can be interpreted as a maintenance measure to keep the system or sub-assembly in order to keep operating in accordance with its function by preparing systematic inspection, detection, and correction on minor damage to prevent the occurrence of greater damage.

- Reactive Maintenance, this type of treatment is also known as breakdown, justifying in case of damage. 
- Prediction and inspection tests Although many methods can be used to determine the PM schedule, there is no valid before the age-derived reliability of a component.

- Proactive Maintenance, this type of treatment helps improve care through actions such as better design, workmanship, installation, scheduling, and maintenance procedures.

In this research needed some supporting data in order to get result which according to purpose. The data presented in this study based on conditions that are in accordance with what is happening in the company. . Presentation of data in this study based on data obtained through questionnaires. The data will be used as supporting data in performing the calculation process using the Minitab tool. So from the calculation using the tool can schedule preventive maintenance. Data from the questionnaire follows all components of the WTP system, for information on which components are most commonly damaged. After that all data obtained is calculated RPN value (Risk Priority Number) to be able to determine which components requires scheduling preventive maintenance. The results of the questionnaire data are presented in Table 1

\section{RESULT AND DISCUSSION}

Based on the results of the RPN table above, then the highest RPN values are:

1. Sandfilter with value 384

2. Cartridge filter with value 378

3. Bag filter with value 343

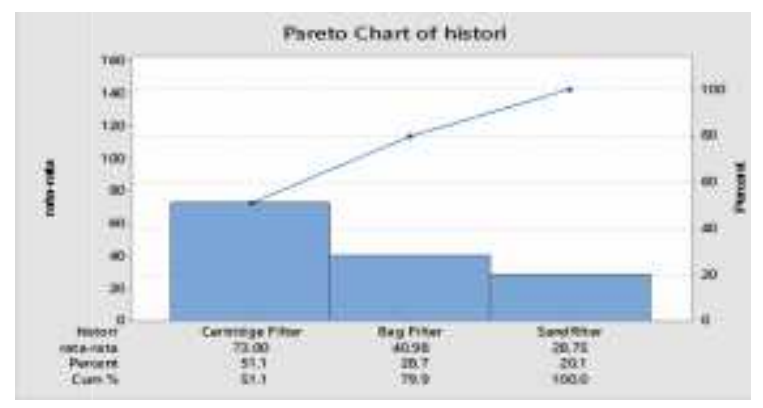

Figure 2. Pareto Diagram Data of MTTR Sandfilter, Bag Filter, Cartridge Filter on WTP machine

From the table above can be seen that the highest average MTTR between the three history is on the filter cartridge that is equal to
73.00 minutes and the smallest average among the three history is at the sandfilter that is equal to 28.75 minutes.

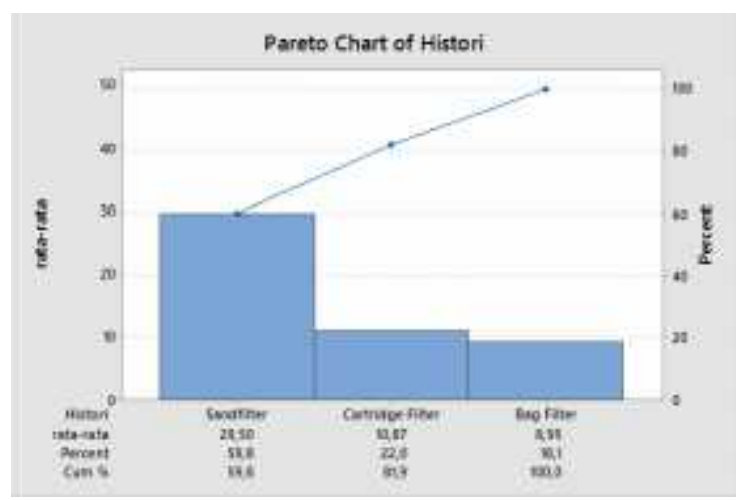

Figure 3. Pareto Diagram MTBF Sandfilter Data, Bag Filter, Cartridge Filter on WTP machine

From the table above can be seen that the average MTBF highest among the third history is on the sandfilter is equal to 29.50 days and the smallest average among the three history is in bag filter that is equal to 8.95 days.

\section{Sandfilter Data Processing}




\section{TiBuana}

Journal of applied Industrial Engineering-University of PGRI AdiBuana

The collected sandfilter data will be processed using minitab as below.

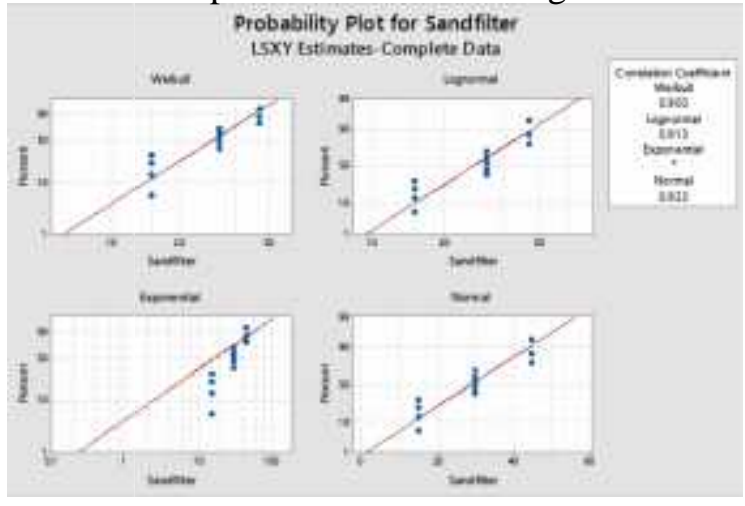

Figure 4. Index Of Fit MTTR Data Sandfilter Components

From the result of processing of Index Of Fit with minitab 17, it can be concluded that the probability value of sandfilter component there is some data out of the ring. From the result above we get value of weibull estimation equal to 0,903 ; lognormal of 0.913 ; exponential of -; and normal at 0.923 . From the calculation with minitab 17 software shows the lowest value is weibull while the highest value is normal.

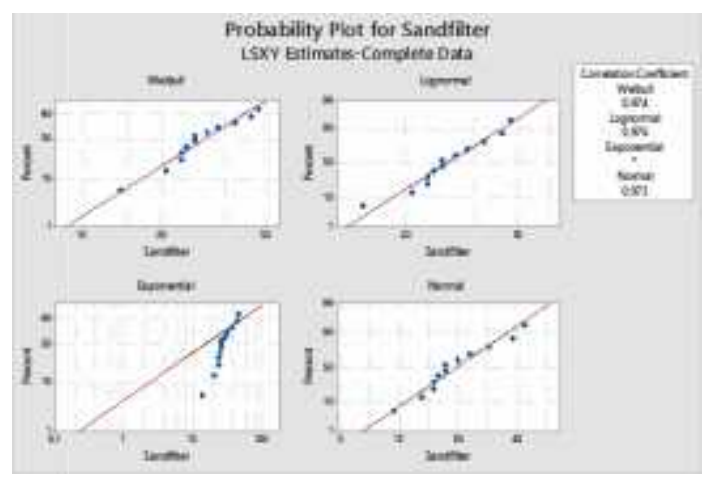

Figure 5. Index Of Fit MTBF Data Sandfilter Components

From Index Of Fit processing with minitab 17, got the biggest value for MTBF data of sandfilter component is to use the lognormal distribution with $\mathrm{r}=0.976$.

\section{Data Processing Bag Filter}

The data bag that has been collected will be processed using minitab as below.

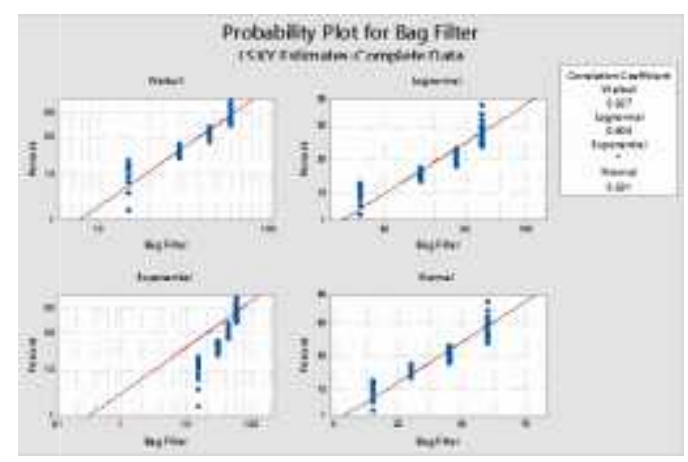

Figure 6. Index Of Fit MTTR Data Filter Bag Component 


\section{TiBuana}

Journal of applied Industrial Engineering-University of PGRI Adi Buana

From Index Of Fit processing results with minitab 17 , it can be concluded that the probability value of the bag component filter there are some data outof the ring. From the result above we get value of weibull estimation equal to
0,927 ; lognormal of 0.903 ; exponential of ; andnormal at 0.931 . From calculations with minitab 17 software shows the lowest value is lognormal while the highest value is normal.

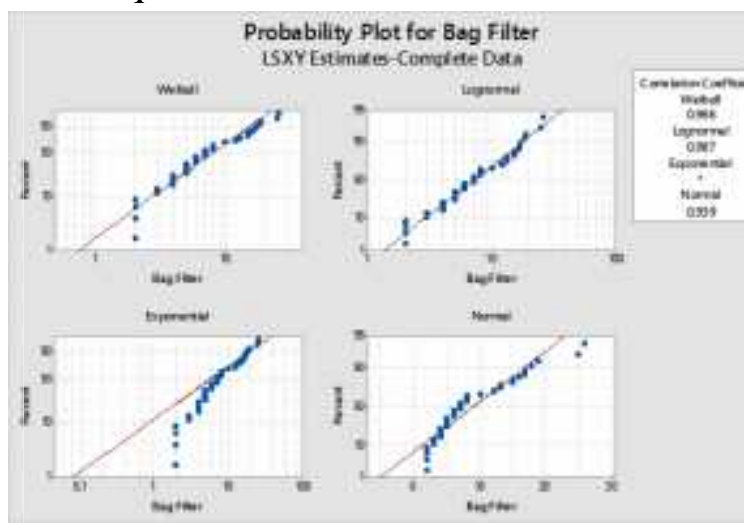

Figure 7. Index Of Fit MTBF Data Filter Bag Components

From the processing of Index Of Fit with minitab 17, obtained the value the largest for MTBF data bag filter component is to use lognormal distribution with $\mathrm{r}=0.987$.

\section{Data Processing Cartridge Filter}

The filter cartridge data already collected will be processed using minitab as below.

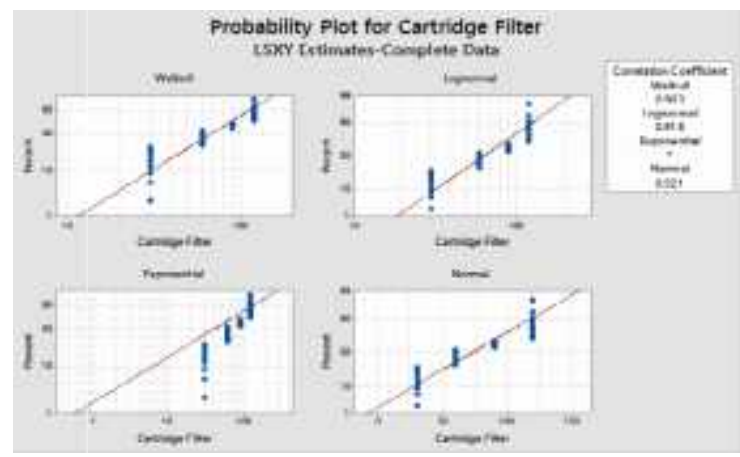

Figure 8. Index Of Fit MTTR Data Components Cartridge Filter

From Index Of Fit processing results with minitab 17 , it can be concluded that the probability value of the component Cartridge filters contain some data that comes out of the ring. From the result above we get value of weibull estimation 0.903; lognormal of 0.918; exponential of -; and normal for 0.921 . From the calculation with minitab 17 software shows the lowest value is weibull while the highest value is normal. 
TiBuana

Journal of applied Industrial Engineering-University of PGRI AdiBuana

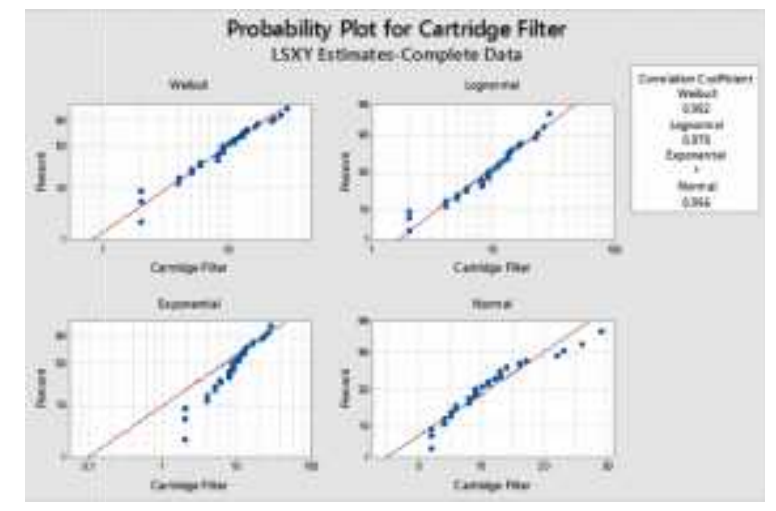

Figure 9 Of Fit Data MTBF Component Cartridge Filter

From Index Of Fit processing with minitab 17, obtained the largest value for the MTBF data of the filter cartridge component is by using the weibull distribution with $\mathrm{r}=$ 0.982 .

The data already processed above will then be analyzed to be able determine the scheduling of all three components that are often damaged. Analysis which is done is as follows:

Calculation of MTBF, MTTF and MTTR Of the three machines that often suffered damage can be determined MTBF, MTTF and MTTR for policies in taking action where during the maintenance and duration which must be resolved.

Table 2. Calculation Table of MTTR, MTTF, and MTBF

\begin{tabular}{ccccc}
\hline Name of Componen & Damage & $\begin{array}{c}\text { MTTR } \\
\text { (hours) }\end{array}$ & $\begin{array}{c}\text { MTTF } \\
\text { (hours) }\end{array}$ & $\begin{array}{c}\text { MTBF } \\
\text { (hours) }\end{array}$ \\
\hline Sandfilter & 12 & 0 & 684 & 708 \\
Bag filter & 41 & 0 & 190,3 & 214,8 \\
Cartride filter & 30 & 1 & 236,8 & 260,8 \\
\hline
\end{tabular}

The data already processed using minitab, then calculated for looking for realibility. Data is calculated as below:

Table 3. Table of Reliability Calculations

\begin{tabular}{|c|c|c|c|c|c|c|}
\hline $\begin{array}{c}\text { Name of } \\
\text { Component }\end{array}$ & Damage & $\begin{array}{l}\text { Down } \\
\text { time }\end{array}$ & $\begin{array}{c}\text { TTF } \\
\text { (hours) }\end{array}$ & $\begin{array}{c}\text { Distribution } \\
\text { patterns }\end{array}$ & Parameter & Realibility \\
\hline Sand filter & 12 & 5,76 & 8208 & Lognormal & $=6,5$ & 0,178527412 \\
\hline Bag filter & 41 & 27,88 & 7728 & Lognormal & $\mathrm{S}=0,7460 \mathrm{tmed}=21$ & 0,005394050 \\
\hline Cartridge filter & 30 & 36 & 7104 & Weibull & $\eta=12.0945 \beta=1,7090$ & 0,008884653 \\
\hline
\end{tabular}

The above calculated data resulted reliability of the analyzed WTP component, ie sandfilter with realibility value 0.178527412 , bag filter with realibility value 0.005394050 , and cartridge filter with realibility value 0,008884653 .

\section{CONCLUSION}

The data already analyzed above resulting in repair time intervals and checking of WTP machine components. In addition to improvements and checks there are reliability results on all three components of the WTP engine. The results of the above analysis are as follows:

The result of time interval of improvement (MTTR) in the above three components is sandfilter with average 0.48 hours, bag filter with an average of 0.68 hours, and filter cartridge with average 1.22 hours per year.

The result of time interval checking analysis (MTTF) on the third the above components are sandfilter with an average of 684 hours, bag filter with average 190.3 hours 


\section{TiBuana}

Journal of applied Industrial Engineering-University of PGRI Adi Buana

and cartridge filter with an average of 236.8 hours per year.

The result of time interval checking analysis (MTBF) at the three components above are sandfilter with an average of 708 hours, bag filter with average 214,8 hours and

\section{REFERENCES}

1. AWWA, 1971.WaterQualityand Treatment, AWWA, Inc. UAS.

2. Ebeling, C.E. 1997. An Introduktion reliabilityandMaintainability Engineering. The MC.Graw Hill CompanierInc. New York.

3. Febianti, Evi. 2016. UsulanPerancangan PerawatanMesin RoughingStand DenganPendekatanReabilityCente r Maintenance(RCM),Seminal NasionalIENACO-2016,ISSN23344349.

4. Hakim, Legisnal. 2010. Aplikasi Komponen RCM Program PemeliharaanPencegahanSebagai

Parameter Ketersediaan dan Tingkat Kegagalan padaPeralatan Pengolahan CPOdi PabrikKelapa SawitRSI, JurnalAPTEKVol3No1.

5. Hanif, Richma. 2015. Perbaikan Kualitas ProdukKeraton LuxuryDiPt $\mathrm{X}$ Dengan Menggunakan FMEA Dan FTA, Reka Intagra ISSN2338-5081, JurusanTeknikIndustriItenasNo 03 Vol.03.

6. Kurniawan, Fajar. 2013. Manajemen Perawatan Industri. Yogyakarta Grahallmu,ISBN978-602-262037-2. cartridge filter with an average of 260.8 hours per year.

Results of reliability analysis (realibility) on the third above component is sandfilter with value 0,178527412 , bag filter with value 0,005394050 , and filter cartridge with value 0,008884653 .

7. Leicth, 1995. RealibilityAnalisis For Engineering:An Introduction. Montgomery, James, 1985.Water TreatmentPrinciples andDesign, A Wiley-Interscience publication, John Wiley\&Sons, NewYork.

8. MukhtarAli,M. N. 2016. Simulation of IroningProsesforBulletCase

MinimumFormingForce with Variation ofDie Angleand ReductionWallThickness.

9. Palit, Herry. 2012.Perancangan RCM untukMengurangiDowntime Mesin padaPerusahaan Manufaktur Aluminium, ProsidingSeminar NasionalManajemenTeknologiXV , ISBN978-602-97491-4-4.

10. Septyani, Sally. 2015. Penentu Waktu IntervalWaktu Perawatan Komponen Kritis Pada MesinTurbin DiPTPLN(PERSERO)Sektor PembangkitOmbilin,Jurnal OptimasiSistemIndutri, Vol14 No 2.

11. Setyadi, Indra. 2014. Analisis Penyebab Kecacatan ProdukCelanaDenganmenggunaka nMetodeFTA dan FMEAdi CVFragile DinCo. 